\section{BURNOUT IN MEDICAL STUDENTS IN SERBIA- PRECLINICAL AND CLINICAL DIFFERENCES}

\author{
Sreten Vićentić ${ }^{1}$ \\ Milan Latas ${ }^{1,2}$ \\ Jasmina Barišić ${ }^{1}$ \\ Marija Matić2 \\ Maja Pantović Stefanović \\ Aleksandar A. Jovanović ${ }^{1,2}$ \\ Srđan Milovanović ${ }^{1,2}$
}

1 Clinic for Psychiatry, Clinical Center of Serbia, Belgrade, Serbia

2 School of Medicine, University of Belgrade, Belgrade, Serbia

\section{Summary}

Introduction/objective: The burnout syndrome is insufficiently investigated within the population of students. The aim of this study was to determine the level of burnout in medical students of medicine in Belgrade with the emphasis on preclini$\mathrm{cal} /$ clinical differences, as well as differences according to gender and average grade.

Methods: The Maslach Burnout Inventory Student Survey (MBI SS) was used to conduct the research among the students of medicine, consisting of emotional exhaustion subscale (MBI-EE), cynicism subscale (MBI CY) and academic efficiency subscale (MBI EF).

Results: High level of burnout according to the MBI EE of the entire sample was confirmed in $84.4 \%$ of students; medium level of burnout according to the MBI CY in $40.7 \%$ and high in $31.7 \%$. According to the MBI EF, $61.2 \%$ of the students had a medium and $16.9 \%$ high level of burnout. The MBI EE and MBI EF scores were significantly higher in first year students, while the MBI CY score was higher with fifth year students $(\mathrm{p}<0.01)$. No gender difference was detected $(p>0.05)$ nor was the difference between the students with higher and lower average grade ( $\mathrm{p}>0.05)$ detected.

Conclusion: The high burnout level in this study indicates the need for research on a larger sample, aiming at preserving the health of the future medical practitioners. It also causes concern about high scores especially in the preclinical, as well as in the clinical academic years.

Key words: syndrome, burnout, medical students, undergraduate, studies 


\section{INTRODUCTION}

The burnout syndrome studies around the world and in our country, conducted within the past twenty and something years, indicate that the individuals employed in health and social services, the so called 'helping services' have a higher inclination to develop a such syndrome, especially if they are confronted with violence, emotional abuse and deaths [1, 2]. Emotional (and physical) exhaustion, depersonalization (altered treatment of patients with negative and cynical attitude, lack of care, attaching stereotypes to patients and emotional distancing from them), altered perception of their ability to work and its subsequent loss (lack of professional competence and success, reduced efficiency at work) are given as the most significant components of this syndrome among health care professionals [3].

The burnout syndrome is described in the professional literature of the students of medicine, but the number of publicati$\rightarrow \quad$ ons is negligible in comparison with the $\ddot{H}$ ones referring to the employed [4-7]. $\therefore$ Analogous to the aforementioned, the a main components of the syndrome in the student population are a sense of emotional exhaustion due to their studies (fatigue at the end of their day at the faculty and general tiredness), cynicism (diminished interest in and enthusiasm for their studies, suspicion in the benefits and significance of their studies) and diminished academic efficacy (diminished efficiency in problem solving during the studies and in dealing with the material required for the studies) [8]. The burnout research of the students of medicine was mostly focused on the students of the final years [7], while one smaller part compared the differences in the level of the burnout during the preclinical and clinical years of the studies [9-13]. In further studies dealing with this difference, the MBI-HSS version of the questionnaire intended for the employed or its partial modifications will be used [7, 12-14].

While observing the connection between the demographic factors and the burnout syndrome within the students, the analysis according to the sex showed extremely heterogeneous results $[13,14]$.

According to our findings, the information in the world literature on connections between students' average grade and the level of burnout are very scarce.

The primary aim of this study was to determine the burnout risk level with the students of the Faculty of Medicine in Belgrade. The secondary aims were to investigate the differences in the level of burnout with the students of the first year (preclinical level) and the fifth year (clinical level), as well as the difference between male and female students, and between the students with higher and lower average grade.

\section{MATERIAL AND METHODS}

\section{Study design and participants}

The research was devised as a crosssection study and it was conducted at the beginning of 2012 at the School of Medicine of University of Belgrade. A total of 280 questionnaires were handed out, 237 students took part in it, 123 students of the first year and 114 students of the fifth year of studies, which represents a high response rate of $85 \%$. There were 45 male and 78 female respondents in the first year and 40 male and 74 female respondents in the fifth year of studies. Re- 
garding the age, both groups were homogenous $(p>0.05)$. Since the first year students did not have the representative number of exams, only the fifth year students responded to the questions about their average grade (only three withheld such information). Regarding the arithmetic mean, they were categorized as students with higher and lower average grade.

\section{Data collection}

The questionnaire was handed out to the first year students at the beginning of the second semester, while it was handed out to the fifth year students also at the beginning of the second semester of the current year which is during their tenth semester. Following the explanations for this type of research, all the participants gave their informed consent and were able to reply anonymously.

The research was permitted by the ethical committee of the School of Medicine of the University of Belgrade.

\section{Instruments}

The most common instrument to measure the burnout syndrome, also used in this study, is the Maslach Burnout Inventory - MBI [2]. The MBI-GS version (General Survey) measures the burnout risk in professions not directly oriented to people and has 3 subscales: emotional exhaustion, cynicism and professional efficiency [9]. The MBI-GS was modified for the purpose of determining the burnout level in students (for example, 'I feel exhausted with my job' was replaced by 'I feel exhausted with my studies' [10]) and measured the level of emotional exhaustion, cynicism and professional success in students [11]. The MBI-SS (Student Survey)
[8] is comprised of 15 claims divided into 7 categories ranging from 0 to 6 ( 0 - never, 1 - a couple of times a year or less frequently, 2 - twice a month or less frequently, 3 - a couple of times a month, 4 once a week, $5-$ a couple of times a week, 6 - every day).

The Emotional exhaustion subscale (MBI-EE) is consisted of 5 items; the cynicism subscale (MBI-CY) of 4 and the academic efficacy subscale (MBI-EF) of 6 items. Each subscale results are presented within 3 categories of the burnout risk as low, medium and high burnout risk.

\section{Statistical analysis}

The description of the numeric features was conducted by the means of the classical methods of descriptive statistics, which are the arithmetic mean and median. For the comparison of the mean values of the parametric features, i.e. the burnout scores of first and fifth year students, and the difference between the male and female students, we used the Student's t-test. The Non-parametric MannWhitney test was used to determine the difference between the burnout levels in students with higher and lower average grade, and the Pearson's correlation was used to show the connectivity of average grade and Burnout subscales' scores. The SPSS program V.15, was used to conduct the statistical data analysis.

\section{RESULTS}

The analysis of the reliability of the subscales showed satisfactory results. Cronbach's alpha coefficient for all three subscales was higher than 0.7 that is 0.83 for MBI EE, 0.79 for MBI CY and 0.81 for MBI EF. 
According to the distribution of the burnout risk categories, the overall sample showed that a high risk of emotional exhaustion was present among $84.4 \%$ of students and that as many as $94.3 \%$ of the first year students and $73.7 \%$ of the fifth year students had a high burnout risk. Furthermore, the subscale of cyni- cism (MBI CY) on the overallsample showed a medium level of the burnout risk of $40.7 \%$ and a high of $31.7 \%$ and that the fifth year students have a higher occurrence of the burnout risk $(41.2 \%)$ than the first year students $(22.8 \%)$. Similarly, the MBI EF showed that $61.2 \%$ of all respondents were in the category of

\begin{tabular}{|c|c|c|c|c|c|c|c|}
\hline & \multirow{3}{*}{ Subscales } & \multicolumn{6}{|c|}{ Year } \\
\hline & & \multicolumn{2}{|c|}{ First } & \multicolumn{2}{|c|}{ Fifth } & \multicolumn{2}{|c|}{ Total } \\
\hline & & $\mathrm{N}$ & $\%$ & $\mathrm{~N}$ & $\%$ & $\mathrm{~N}$ & $\%$ \\
\hline \multirow{4}{*}{ MBI EE } & low burnout risk & - & - & 2 & 1.8 & 2 & 0.8 \\
\hline & medium burnout risk & 7 & 5.7 & 28 & 24.6 & 35 & 14.8 \\
\hline & high burnout risk & 116 & 94.3 & 84 & 73.7 & 200 & 84.4 \\
\hline & Total & 123 & $100 \%$ & 114 & $100 \%$ & 237 & $100 \%$ \\
\hline \multirow{4}{*}{ MBI CY } & low burnout risk & 44 & 35.8 & 21 & 18.4 & 65 & 27.4 \\
\hline & medium burnout risk & 51 & 41.5 & 46 & 40.4 & 97 & 40.9 \\
\hline & high burnout risk & 28 & 22.8 & 47 & 41.2 & 75 & 31.7 \\
\hline & Total & 123 & $100 \%$ & 114 & $100 \%$ & 237 & $100 \%$ \\
\hline \multirow{4}{*}{ MBI EF } & low burnout risk & 33 & 26.8 & 19 & 16.7 & 52 & 21.9 \\
\hline & medium burnout risk & 78 & 63.4 & 67 & 58.8 & 145 & 61.2 \\
\hline & high burnout risk & 12 & 9.8 & 28 & 24.6 & 40 & 16.9 \\
\hline & Total & 123 & $100 \%$ & 114 & $100 \%$ & 237 & $100 \%$ \\
\hline
\end{tabular}

\begin{tabular}{|c|c|c|c|c|c|c|}
\hline & $\begin{array}{l}\text { Year of } \\
\text { training }\end{array}$ & $\mathrm{N}$ & Mean & SD & $\mathrm{t}$ & $\mathrm{p}$ \\
\hline \multirow{2}{*}{ MBI EE } & $1 \mathrm{st}$ & 123 & 20.63 & 4.59 & \multirow{2}{*}{3.064} & \multirow{2}{*}{0.002} \\
\hline & 5 th & 114 & 18.46 & 6.25 & & \\
\hline \multirow{2}{*}{ MBI CY } & $1 \mathrm{st}$ & 123 & 4.93 & 4.51 & \multirow{2}{*}{-5.007} & \multirow{2}{*}{0.000} \\
\hline & 5 th & 114 & 8.55 & 6.50 & & \\
\hline \multirow{2}{*}{ MBI EF } & $1 \mathrm{st}$ & 123 & 27.41 & 4.62 & \multirow{2}{*}{3.232} & \multirow{2}{*}{0.001} \\
\hline & 5th & 114 & 25.02 & 6.68 & & \\
\hline
\end{tabular}


medium burnout risk and $16.9 \%$ in the category of high burnout (Table 1).

Table 2 shows a statistically higher significant differences $(\mathrm{p}<0.01)$ between the values for all three subscales for the first and fifth year students. The MBI EE and MBI EF were higher with the first year students, while the MBI CY was higher with the fifth year students.

Although the high and medium burnout risk was dominant with both sexes, there were no statistically significant differen-

\begin{tabular}{|c|c|c|c|c|c|c|}
\hline & Gender & $\mathrm{N}$ & Mean & SD & $\mathrm{t}$ & $\mathrm{p}$ \\
\hline \multirow{2}{*}{ MBI EE } & male & 85 & 18.95 & 5.71 & \multirow{2}{*}{-1.309} & \multirow{2}{*}{0.192} \\
\hline & female & 152 & 19.93 & 5.44 & & \\
\hline \multirow{2}{*}{ MBI CY } & male & 85 & 6.45 & 6.13 & \multirow{2}{*}{-0.449} & \multirow{2}{*}{0.654} \\
\hline & female & 152 & 6.80 & 5.68 & & \\
\hline \multirow{2}{*}{ MBI EF } & male & 85 & 25.65 & 5.92 & \multirow{2}{*}{-1.217} & \multirow{2}{*}{0.225} \\
\hline & female & 152 & 26.61 & 5.75 & & \\
\hline
\end{tabular}

\begin{tabular}{|c|c|c|c|c|c|}
\hline \multicolumn{7}{|c|}{ Table 4. Burnout score vs. lower/higher grade in the fifth year students } \\
(Mann-Whitney test)
\end{tabular}

Table 5. Correlation of the average grade and the Burnout subscales' scores

\begin{tabular}{|c|c|c|c|c|}
\hline \multicolumn{4}{|c|}{ MBI EE MBI CY } & MBI EF \\
\hline \multirow{3}{*}{$\begin{array}{l}\text { Average } \\
\text { grade }\end{array}$} & $\begin{array}{c}\text { Pearson } \\
\text { Correlation }\end{array}$ & -0.082 & -0.085 & $0.196^{*}$ \\
\hline & Sig. (2-tailed) & 0.395 & 0.378 & 0.040 \\
\hline & $\mathrm{N}$ & 111 & 111 & 111 \\
\hline
\end{tabular}

* Correlation is significant at the 0.05 level (2-tailed)

** Correlation is significant at the 0.01 level (2-tailed) 
ces $(p>0.05)$ in the analysis according to the gender of the students (Table 3 ).

The arithmetic mean of the average grade for the 111 fifth year students was 8.29. Forty-three students had the average grade higher than 8.29 and 68 students lower than that. By observing the connection between the burnout risk and the average grade, we confirmed no significant difference $(\mathrm{p}>0.05)$ in the MBI EE and MBI EF subscales. Only in the MBI CY subscale, the students with a lower average grade had significantly higher values $(\mathrm{p}$ $<0.01$ ) (Table 4).

Further, the Pearson correlation of average grade and subscales' scores showed significancy $(\mathrm{p}<0.05)$ only in the MBI EF subscale (Table 5).

\section{DISCUSSION}

The aim of this study was to determine the prevalence of the burnout risk in the students of the Faculty of Medicine and to investigate the possible differences in terms of preclinical and clinical years of studies, gender and average grade.

The burnout risk analysis (Table 1) showed that according to the MBI EE subscale, which is highly representative [2], as many as $84.4 \%$ of students, $94.3 \%$ of the first year students and $73.7 \%$ the fifth year students had a high burnout risk. The MBI CY subscale showed a prevalence of a medium (moderate) risk with $40.9 \%$ and a high with $31.7 \%$, where $72.6 \%$ of the overall sample was exposed to a medium and high level of risk. According to the MBI EF subscale of academic efficiency, $61.2 \%$ and $16.9 \%$ of the students had a medium and high burnout risk respectively. All these figures are higher than in currently available studies worldwide. According to the eminent work of the Uni- versity of Manchester, the burnout risk rate was considerably lower and ranged between $5.2 \%$ for the MBI EF up to $7.1 \%$ for the MBI CY (that is DP-depersonalization since the MBI-HSS version was used) and up to $16.1 \%$ for the MBI EF (that is PA) [13]. Even though they used another, also verified instrument to measure the burnout (Oldenburg Burnout Inventory), Dalin and Runesson (1997) reported a high prevalence of the burnout from 21.7 $\%$ to $54.3 \%$ [15]. Similarly, data from an investigation in Nashville in the USA confirmed a moderate and high burnout ranging from 21 to $43 \%$ [14], while results published in Australia ranged from $14 \%$ for the MBI EE to $27 \%$ for the MBI CY (that is DP) [7]. Generally speaking, a high level of burnout in students was caused by both the organization of lectures at faculty and the quality of their lifestyle [15-20]. Hypothetically, the difference in the curriculum would be only one of the reasons for such a significant discrepancy between the results we obtained and the results found in the world literature. However, such a high burnout rate raises and imposes the need for a thorough investigation of the problem among students, and subsequently for a certain international study.

There is a significant difference in the results between preclinical (first, second, third) and clinical (fourth, fifth and sixth) years of medical studies, especially regarding the organization of the lectures [10]. In the clinical years of the studies, the students mostly have practical lectures in hospitals and are in direct contact with the patients while in the preclinical years of the studies, the students mostly have theoretical lectures with minimum contact with patients [10]. Our study confirmed significantly higher statistical results $(p<0.01)$ on the MBI EE and MBI EF sca- 
les in the first year students and on the MBI CY subscale in the fifth year students (Table 2). It might be possible to explain the difference with the fact that the first year students encounter the faculty for the first time, which, as opposed to highschool, has a different organization of the lectures and practice resulting in a certain level of fear of the new education system where they have to familiarize with the new curriculum and meet each other. In addition, moving to Belgrade (the capital city) and separation from family can also be factors that cause stress [21, 22]. The difference in the burnout level could be explained by the curriculum difference in the first (preclinical) and the fifth (clinical) years of studies. The fifth year students are 'at the end' of their studies, which might imply they are more satisfied and disburdened as they are about to finish their studies. If we look at one of the definitions of the cynicism subscale (MBI CY), as 'diminished interest in and enthusiasm about studying', then the higher values with clinical of the fifth year students would be expected. There are different findings in the international literature, however. Research conducted among the students of medicine in Spain showed a high burnout risk among $14.8 \%$ of the third year students and $37.5 \%$ of the sixth year students, which is inverted in comparison with our results where the preclinical students had a significantly higher scores [10]. However, this study takes into account the third year of studies as preclinical, which differs from the first year (preclinical year in our study) since we expect that the students have adapted and acquired certain experience during the first two years and as a result have a lower adaptation stress. The aforementioned research of the University of Manchester showed that the fifth year stu- dents a had higher burnout risk than the first year students, but that this difference was statistically insignificant [13]. The differences in the organization and content of lectures, at least in certain segments, contribute to the heterogeneous results of the students in Belgrade when compared with their counterparts in other countries. In spite of the obvious significance of the analysis of the above mentioned results, it currently exceeds the framework of this research. In the light of the extremely high burnout rate in the first year of studies, it might be concluded that future research of chronologically following the level of burnout at the beginning, middle and end of the first year could produce more solutions to the problem.

Research of the problem of burnout with male and female students also gave different results. Some show that there is a significant difference, and that the males are exposed to the higher burnout risk [7] while other show no difference at all [14, $23,24]$. Others show that the females have a higher burnout risk [25, 26]. Our research showed that a slightly higher number of women had a borderline scores of high burnout risk. However, this difference according to the gender was not statistically significant (Table 3 ). This result could be substantiated by a bigger participation of women in the overall student sample.

The analysis of the burnout risk levels between students with higher and lower average grade (Table 4) showed that the students with a somewhat lower average grade had subsequently a higher burnout risk, but that, apart from the MBI CY subscale, this difference was statistically insignificant. According to our literature, research analyzing the connection between the burnout level and the average grade are very rare. Some of the results showed no 
statistically significant connections [27] while others showed a small and statistically negative connection between the burnout level and the average grade during one's studies [28], which is in compliance with our findings on the MBI CY subscale. The correlation of the average grade in total of the fifth year sample and subscales' scores showed significancy $(\mathrm{p}<0.05)$ only in the MBI EF subscale (Table 5), which is also consistent with the above mentioned results.

However, this study has its limitations. Firstly, the sample, although marked as a larger sample, should be additionally enlarged with other Universities in the country as, according to our knowledge, there are certain differences in curriculums. Secondly, the design of the study could be taken as another disadvantage as the crosssection study does not allow establishing of a causative link between the variables where prospective design would probably give much more information. Furthermore, it would be advisable to enlarge the range of the socio-demographic variables i.e. questions on the quality on one's life, in future research.

It would be also interesting to include the question about the idea of dropping out of (or changing) medical studies since certain studies support such an approach $[17,29]$. However, it would be important to investigate the psychological profile of the students as an obvious factor that affects the level of the burnout risk [30,31], unfortunately it wasn't a primary goal of this study.

One of the advantages of our study is the fact that, according to our knowledge, the research into burnout risk had never been conducted among preclinical students of medicine in our country and is seen as necessary in the light of the delicate and stressful nature of the profession these students are studying for [12]. It is also important to investigate the burnout risk in all the years of studies as the burnout risk level is reversible among the students and there is also a possibility of recovery within one year (around $26 \%$ ) [13]. Generally speaking, only a small number of published researches compare the clinical and preclinical differences in the level of the burnout risk with the students of medicine. It is also important to emphasize that the most refined and highly verified burnout evaluation instrument, the MBISS version [8], was used in our study, as opposed to most research worldwide where the MBI version for the employed $[2,9]$ or its modification was applied.

\section{CONCLUSIONS}

The burnout syndrome among students is an area that needs to be explored in our country, not only among the students of medicine, especially in the light of the fact that there is insufficient research done on this subject.

The extremely high burnout risk rate ranging from $31.7 \%$ to as high as 94.3 $\%$, according to the different MBI subscales among the first year and the fifth year students of the School of Medicine in Belgrade is alarming and worrying. These burnout findings imply serious need for further and more thorough evaluation of such a complex problem, especially for the purpose of protecting mental health of the future medical practitioners as well as for the purpose of more precise definition of the factors that affect the quality of studying. It would be also important to implement some educational programs that would assist the students in developing necessary strategies and skills of defense in contact with patients as well as in everyday lectures at their faculties. 


\section{SINDROM SAGOREVANJA KOD STUDENATA MEDICINE U SRBIJI \\ - PREDKLINIČKE I KLINIČKE RAZLIKE}

\section{Sreten Vićentić ${ }^{1}$ \\ Milan Latas ${ }^{1,2}$ \\ Jasmina Barišić ${ }^{1}$ \\ Marija Matić 2 \\ Maja Pantović Stefanović ${ }^{1}$ \\ Aleksandar A. Jovanović ${ }^{1,2}$ \\ Srđan Milovanović1,2}

1 Klinika za psihijatriju, Klinički centar Srbije, Beograd, Srbija

2 Medicinski fakultet, Univerzitet u Beogradu, Beograd, Srbija

\section{Kratak sadržaj}

Uvod/cilj: Sindrom sagorevanja je nedovoljno istražen u studentskoj populaciji. Cilj rada bio je utvrđivanje nivoa "sagorevanja" kod studenata medicine u Beogra$\mathrm{du}$, sa akcentom na razlike izmedju grupe studenata koja pohadja nastavu iz predkliničkih i grupe studenta koja pohadja nastavu iz kliničkih predmeta, kao i razlike prema polu i prosečnoj oceni.

Metode: Korišćen je Masleč Inventara Izgaranja za ispitivanje studenata (MBISS), koji se sastoji iz subskale emocionalne iscrpljenosti (MBI EE), subskale cinizma (MBI CY) i akademske efikasnosti (MBI EF).

Rezultati: Visok rizik za "sagorevanje" na MBI EE u ukupnom uzorku imalo je $84,4 \%$ studenata, na MBI CY se beleži srednji nivo "sagorevanja" od 40,7 \% i visok od 31,7 \%, a na MBI EF 61,2 \% ima srednje "sagorevanje", i 16,9 \% visok. Skorovi na MBI EE i MBI EF viši su značajno kod studenata prve, dok su na MBI CY viši kod studenata pete godine $(\mathrm{p}<0,01)$. Razlika prema polu nije nađena ( $p>0,05)$, kao ni razlika kod studenata sa nižim i višim prosekom ( $p>0,05)$.

Zaključak: Visok nivo "sagorevanja" $\mathrm{u}$ ovoj studiji implicira potrebu za istraživanjem na većem uzorku radi očuvanja zdravlja budućih lekara. Takođe, zabrinjava što su visoki skorovi dobijeni i na prekliničkim i kliničkim godinama studija.

Ključne reči: sindrom, sagorevanje, studenti medicine, osnovne studije 


\section{References:}

1. Weber A, Jaekel-Reinhard A. Burnout syndrome: a disease of modern societies. Occup Med 2000; 50(7): 512-7

2. Maslach C, Jackson SE, Leiter M. Maslach Burnout Inventory, Manual. Palo Alto California: Consulting Psychologists Press, Inc 1996.

3. West CP, Dyrbye LN, Sloan JA, Shanafelt TD. Single item measures of emotional exhaustion and depersonalization are useful for assessing burnout in medical professionals. Journal of general internal medicine 2009; 24(12): 1318-21

4. Shanafelt TD, Bradley KA, Wipf JE, Back AL. Burnout and self- reported patient care in an internal medicine residency program. Ann Intern Med. 2002; 136: 358-67

5. Kahill S. Symptoms of professional burnout: A review of the empirical evidence. Canadian Psychology 1988; 284-97

6. Whitley TW, Allison EJ Jr, Gallery ME. Work-related stress and depression among practicing emergency physicians: an international study. Ann Emerg Med 1994; 23(5): 1068-71

7. Willcock S, Daly M, Tennant C, Allard B. Burnout and psychiatric morbidity in new medical graduates. MJA 2004; 181: 35760

8. Schaufeli WB, Martinez I, Marques Pinto A, Salanova M, Bakker A. Burnout and engagement in university students: a cross-national study. Journal of CrossCultural Psychology 2002; 33(5): 464-81

9. Schaufeli WB, Leiter MP, Maslach C, Jackson SE. The Maslach Burnout Inventory: General Survey (MBI-GS). In: The Maslach Inventory- test manual, 3rd edition. Palo Alto: Consulting Psychologists Press 1996; p. 19-26.
10. Galan F, Sanmartin A, Polo J, Giner L. Burnout risk in medical students in Spain using Maslach Burnout Inventory- Student Survey. Int Arch Occup Environ Health 2011; 84: 453-9

11. Obradović D, Pantić M, Latas M. Procena psihičkog stanja studenata medicinskog fakulteta. Engrami - časopis za kliničku psihijatriju, psihologiju i granične discipline 2009; 31 (3-4): 47-55

12. Guthrie E, Black D, Shaw C. Psychological stress in medical students:a comparison of two very different courses. Stress Med 1997; 13: 179-84

13. Guthrie E, Black D, Bagalkote $H$, Shaw $C$, Campbell M, Creed F. Psychological stress and burnout in medical students: a five years prospective longitudinal study. J R Soc Med 1998; 91: 237-43

14. Đurić V, Latas M, Trajanović N, Jovanović D, Milovanović S. Analiza predispitne nesanice kod studenata Medicinskog fakulteta. Engrami - časopis za kliničku psihijatriju, psihologiju i granične discipline 2009; 31 (1-2): $61-8$

15. Dahlin M, Runeson B. Burnout and psychiatric morbidity among medical students entering clinical training: a three year prospective questionnaire and interview-based study. BMC Med Educ 2007; 7: 6-14

16. Dyrbye LN, Thomas MR, Huntington JL. Personal life events and medical students burnout: a multicenter study. Acad Med 2006; 81: 374-84

17. Dyrbye LN, Thomas MR, Harper W. The learning environment and medical student burnout: a multicenter study. BMC Med Educ 2009; 43: 274-82

18. Dyrbye LN, Thomas MR, Power DV. Burnout and serious thoughts of dropping out of medical school: a multi-institutional study. Acad Med 2010; 85: 94-102 
19. Dyrbye LN, Thomas MR, Massie FS. Burnout and suicidal ideation among US medical students. Ann Intern Med 2008; 149: 334-41

20. Dahlin M, Joneborg N, Runeson B. Performance-based selfesteem and burnout in cross-sectional study of medical students. Med Teach 2007; 29: 43-8

21. Eller T, Aluoja A, Vasar V, Veldi M. Symptoms of anxiety and depression in Estonian medical students with sleep problems. Depression and Anxiety 2006; 23(4): 250-6

22. Johns MW, Dudley HAF, Masterton JP. The sleep habits, personality and academic performance of medical students. Medical Education 2009; 10(3): 158-62

23. Firth J. Levels and source of stress in medical students. BMJ 1986; 292: 1177-80

24. Miller PMcC, Surtees PG. Psychological symptoms and their course in first-year medical students as assessed by the Interval General Health Questionnaire (I-GHQ). Br J Psychiatry 1991; 159: 199-207

25. Borrill CS, Wall MA, West GE. Mental Health of the Workforce in NHS Trusts. Final Report. Sheffield: Institute of Work Psychology, University of Sheffield/Leeds: Department of Psychology, University of Leeds, 1996.

26. Hojat M, Glaser K, Xu G, Veloski JJ, Christian EB. Gender comparisons of medical students' psychosocial profiles. Med Educ 1999; 33: 342-9
27. Balogun JA, Helgemoe S, Pellegrini E, Hoeberlein T. Academic performance is not a viable determinant of physical therapy students' burnout. Perceptual and Motor Skills 1996; 83: 21-2

28. McCarthy ME, Pretty GM, CatanoV. Psychological sense of community and student burnout. Journal of College Student Development 1990; 31: 211-6

29. Costa EFO. Burnout Syndrome and Associated Factors among Medical Students: A Cross-Sectional Study. Clinics 2012; 67 (6): 573-9

30. Ranđelović D, Minić J. Prediktori zadovoljstva životom kod studenata. Engrami- časopis za kliničku psihijatriju, psihologiju i granične discipline 2012; 34: 59-68

31. Lue BH, Chen HJ, Wang CW, Cheng Y,Chen MC. Stress, personal characteristics and burnout among first postgraduate year residents: a nationwide study in Taiwan. Med Teach 2010; 32(5): 400-7

Sreten Vićentić

Clinic of Psychiatry, Clinical Center of Serbia Pasterova 2, Belgrade 11000, Serbia

Tel: +381 113662090

Email: sretenvicentic@gmail.com 